\title{
Steadfastness to Memorize The Koran Viewed from Self-Efficacy, Self-Control, and Self-Management
}

\author{
Nyda Afsari ${ }^{1}$, Nurul Hafizah ${ }^{2}$, Natalia Muzakkar ${ }^{3}$, and H. Fuad Nashori ${ }^{4}$ \\ \{nydaafsari@gmail.com¹, hafizah119@gmail.com², nataliamuzakkar10@gmail.com³ \\ ${ }^{1,2,3}$ Faculty of Psychology and Social Cultural Sciences, Universitas Islam Indonesia
}

\begin{abstract}
Previous study have shown that self-efficacy, self-control, and selfmanagement are important with steadfastness character for someone who memorize the Koran. This study aims to examine the theoretical model between the four variables, the effect of self-efficacy on steadfastness and self-control also selfmanagement as a moderator variable. Respondents in this study were 304 Koran reciters in the age range of 13 to 40 years in Indonesia. The scale used in this study consisted of two adaptation scales from the General Self-Efficacy Scale with $\alpha$ value of 0.813 and the Self-Control and Self-Management Scale with $\alpha$ value of 0.829 . While one other scale called Steadfastness Scale in the Koran Memorization was made referring to Mujib's theory with $\alpha$ value of 0.849 . Data analysis was performed by analyzing structural equation modeling technique with path analysis and using AMOS version 20.00 for Windows. The results of the study showed that this theoretical model is proven through the values of CFI and TLI that meet the standards. Indirectly, self-control and self-management can be a moderator variable for self-efficacy and steadfastness.
\end{abstract}

Keywords: Koran reciters, self-control, self-efficacy, self-management, semantic equational modeling, steadfastness

\section{Introduction}

Indonesia is a warehouse for the hafidz. This is evidenced by the many children of the nation who became hafidz and the many other citizens who came to Indonesia to learn to memorize the Koran. The data submitted by the Nusantara Mengaji Advisory Board states that Indonesia has the highest number of memorizers of the Koran in the world, namely reaching 30 thousand people memorizing the Koran. The hope is that this number can increase every year [1].

The term memorization itself, when viewed from the origin, is derived from Arabic, namely 'hafidza-yahfadzu-hifdzan' which means always remember and slightly forget [2]. Tahfidz is a process of memorizing into the memory that makes someone able to convey it out of head and the name for people who memorize the Koran is called hamil/hamalah Koran or hafidz/huffadz [3]. Memorizing the Koran takes time and this memorizing process is called hifz [4]. Hifz covers a series of processes namely encoding, by giving attention to the verses of the Koran. Furthermore, the process of storing (maintaining/storing), namely by maintaining information that has been encoded, and finally is the process of calling / retrieving information that has been saved by repeating the verse many times.

If viewed from the teachings of Islam, memorizing the Koran has a great virtue and will get rewards such as giving a rewards to his parents in heaven (Narrated by Turmudzi No. 
3164), being a family of Allah SWT (Narrated by Ahmad), and finally getting intercession (help) from the Koran in the Hereafter (Narrated by Muslim No. 1910). The process that goes through continuously and the reward for the success of memorizing the Koran makes the process not easy. Recitation of the Koran requires the strength of character that is able to strengthen it to complete and achieve its desire to become the Koran's hafidz and one of the strengths of character meant is steadfastness.

In connection with steadfastness, in fact, various problems are faced by the reciters of the Koran. Based on Tanjung et al. Research, the problems experienced will make the reciters of the Koran choose to finish memorizing the Koran or stop before reaching the end point [5]. The results of a survey conducted by the researcher to 304 reciters of the Koran in various regions of Indonesia showed that the reciters of the Koran had several obstacles in memorizing the Koran, such as boredom, laziness, fatigue, a less supportive environment, difficult to practice, time management between academic activities and work with time memorization and murojaah, lack of diligence, memorizing difficult verses, and controlling yourself from immorality and playing gadgets. This survey is also supported by the results of interviews conducted with one of the reciters of the Koran with the initial MB. MB is a student who is completing his memorization in one of the Koran memorization foundations in Indonesia. MB stated that the difficulty in memorizing the Koran was felt mainly related to the steadfastness in memorizing and repeating memorization. According to MB, maintaining the steadfastness of memorizing the Koran, MB must be able to control himself to keep away from things that can interfere with the process of memorizing the Koran for example reducing activities that are less important that make it difficult to memorize. Other activities avoided by MB such as social media use, listening to music, disobedience, arrogance, and sleeping for too long. MB said that MB and friends only slept 2 hours every day for one year to memorize the Koran while in preparation class. One that makes it survive is the belief in its ability to complete memorization of the Koran and the existence of family support.

Based on the data already mentioned, it can be said that the reciters of the Koran experienced various problems in memorizing the Koran, but the most important thing is to maintain the steadfastness in memorizing the Koran. According to Tasmara, steadfastness can be interpreted as consistent which means keeping track of the straight path despite many obstacles that stand in the way [6]. Steadfastness is a psychological study which is a form of behavior, namely behavior that carries out goodness permanently, anytime, and anywhere [7]. In psychology studies, steadfastness can be matched with persistence which is an important factor in realizing the desire to achieve a goal despite obstacles, difficulties, or despair [8]. This is in line with the statement of Umar bin Khattab [9] that steadfastness is consistency in carrying out obedience and leaving a prohibition. In addition, Mujib stated that steadfastness can be called mustaqim which means character which is characterized by a consistent alignment between intentions and behavior [10]. This character leads to enthusiasm that can motivate good deeds with discipline or on time, commitment, and high dedication. Mujib mentioned two aspects that exist in steadfastness, namely motives and behavior [10]. Motive is related to one's internal condition and values held, while behavior is related to how a person is able to realize his motives. Based on some of these meanings, steadfastness can also be called consistency, where consistency is identical to persistence which is a form of one's personality in achieving goals needed early [11]. Based on a series of explanations above, steadfastness is considered important because of its role in memorizing the Koran to continuously memorize and recite the memorization.

One of the efforts made by the reciters of the Koran in maintaining steadfastness to memorizing the Koran is by controlling the desires and protection that may hinder the 
memorization of the Koran. Therefore, reciters of the Koran must have good selfcontrol so that each activity can be approved as expected [12]. This is supported by the research of Baumeister et al. [13] that self-control holds an important key to improving the nature and function of self so that self-control has attracted several studios in different contexts, wrong according to what is in persistence or perseverance. Some research results showed self-control of enthusiasm [14] and disciplinary protection [15] students memorizing the Koran. According to Averill [16], self-control is a person's ability to modify behavior, manage important and unimportant information, and choose actions that are believed to be true. Not only self-control, but self-management also plays a role in the process of maintaining steadfastness in memorizing the Koran. A study states that there is a negative relationship between selfmanagement and academic procrastination in active college students and organizations in a university in Indonesia [17]. That is, the higher the self-management possessed, the lower the level of academic procrastination. Also mentioned by Asim that the existence of selfmanagement guidance can improve the discipline of learning high school students [18]. Although it does not directly affect the concept of steadfastness, procrastination and discipline are part of the formation of steadfastness. In this paper, the constructs of self-control and selfmanagement are combined with reference to the views of Mezo [19]. Furthermore, Mezo said that self-control and self-management had three aspects, namely self-monitoring (SM), self-evaluating (SE), and self-reinforcing (SR).

In addition to self-control and self management, the results of interviews indicated that confidence in their ability to memorize the Koran also plays an important role during the memorization process. In the realm of psychology, this is called self-efficacy, which is interpreted by Bandura as a belief in the abilities of a person in carrying out specific tasks [20] and in the context of this research is self-efficacy in memorizing the Koran. In addition, AlBaddareen et al. stated that self-efficacy is students' beliefs about their ability to complete tasks well [21]. Kaiser said that someone who has positive self-efficacy believes that he is able to complete a certain task well and will put forth maximum effort in completing the task undertaken [22]. Zarina stated that someone who has good self-efficacy can be a motivating factor to act and is better able to control stress and anxiety [23]. While someone with low selfefficacy can be an obstacle to achieving his goals. Therefore, self-efficacy can be one of the predictors in predicting and determining academic achievement and will exert effort in completing certain tasks. Furthermore, Bandura said that self-efficacy has three aspects, namely the level of difficulty of the task, generality or broad field of behavior, and strength or stability of beliefs [24].

Based on the description above, it can be seen that there is a link between self-efficacy, self-control, self-management, and steadfastness. Seeing the relationship between the three, the researcher is interested in testing the theoretical model between the three variables on memorizing the Koran. Thus, the hypothesis proposed is "there is a direct effect between selfefficacy towards steadfastness and selfcontrol and self-management as a moderator variable". While the purpose of this study is to examine the theoretical model between self-efficacy, selfcontrol, and self-management of steadfastness in memorizing the Koran.

This study carries a variable that has not been widely discussed in the realm of Islamic psychology, namely steadfastness. Steadfastness in this study was not only studied from the perspective of Islamic psychology, but also on the perspective of contemporary psychology. In addition, the measuring instrument used for the variables in this study (selfcontrol and selfmanagement scale and self-efficacy scale) was the result of adaptation while the steadfastness measuring instrument itself was the design from the researcher. 


\section{Method}

Respondents in this study were male and female memorizers of the Koran in Indonesia with ages ranging from 13 years to 40 years. The selection of respondents was based on the concept of development according to Hurlock [25], namely the age of adolescents ranging from 13 years to 18 years and young adults with a range of 19 years to 40 years. Age selection was also based on the results of research that showed that age differences can affect the decline in memory performance in various tasks and situations, especially in terms of the efficiency of information processing systems [26]. The research respondents were 304 people with 60 people in the teenage category and 244 people in the early adult category. The research respondents involved came from various kinds of non-formal and formal educational backgrounds. The memorization process was carried out in institutions both in Islamic boarding schools, tahfidz communities, and independently. Based on several criteria of respondents that have been explained, it can be said that this study used a sampling technique with purposive random sampling, which is a sampling technique with certain considerations or certain criteria in accordance with the research context [27].

This study used three scales with two scales which are the results of adaptations from previous studies and one scale made by the researcher in accordance with the theory used. These three scales have gone through a series of validation processes and used trials which were then tested for reliability and abortion items. The entire item used a Likert scale with the higher the score, the higher the indication for each variable. This scale was also a dissertation of the approval sheet for respondents.

The first scale called "The Scale of Self-Efficacy in Memorizing the Koran". This scale was the result of an adaptation of The General Self-Efficacy Scale (GSE) [28]. This scale was made by referring to Bandura self-efficacy theory [29] which represents three aspects of selfefficacy, namely the level of difficulty of the task, generality or extent of the field of behavior, and strength or stability of beliefs. The second scale called "Self-Control and SelfManagement in Koran memorization" which is an adaptation of the scale of The Self-Control and Self-Management Scale (SCMS) [19] based on the theory of Self-Control and SelfManagement Skill (SCMSk) [30], [31]. On this scale there were two components measured, namely selfcontrol and self-management. The absence of information related to the blueprint scale made the researcher decided to involve the two components in one unit. This scale represented three aspects, namely self-monitoring (SM), self-evaluating (SE), and selfreinforcing (SR). The third scale called "Steadfastness Scale in the Koran Memorization" made by the researcher based on the construct of steadfastness theory according to Mujib theory [10]. Information for each scale before and after adaptation can be seen in Table 1 and Table 2 .

Table 1. Estimated Item Validity and Scale Reliability Coefficient

\begin{tabular}{lccc}
\hline \multirow{2}{*}{ Scale } & \multicolumn{2}{c}{ Total Item } & Estimated \\
\cline { 2 - 3 } & Before & After & Validity \\
\hline SE & 10 & 8 & $0,362-0,662$ \\
SC and SM & 16 & 10 & $0,395-0,641$ \\
Steadfastness & 13 & 13 & $0,376-0,603$ \\
\hline
\end{tabular}


Table 2. The Result of Scale Reliability Coefficient

\begin{tabular}{lcc}
\hline \multirow{2}{*}{ Scale } & \multicolumn{2}{c}{ Cronbach's Alpha } \\
\cline { 2 - 3 } & Before & After \\
\hline SE & $0,76-0,90$ & 0,813 \\
SC and SM & 0,81 & 0,829 \\
Steadfastness & - & 0,849 \\
\hline
\end{tabular}

The data analysis method used in this study was assisted by the AMOS version 20.00 program for Windows. The data analysis technique used in this study was a structural equation model using path analys.

\section{Result}

In accordance with structural equation models with path analysis technique, the results of the normality test indicated that multivariate c.r was 0.830 . This meets the normality standard which is in the range of values of -2 to 2 . That is, the overall data obtained is normal. This value is corroborated by the Mahalanobis d-squared value which ranges from 3.471 to 18.091 and does not experience an outlier.

The hypothesis that reads "There is the effect of self-efficacy on steadfastness with selfcontrol and self-management as a moderator variable" is proven through the model in Figure 1.

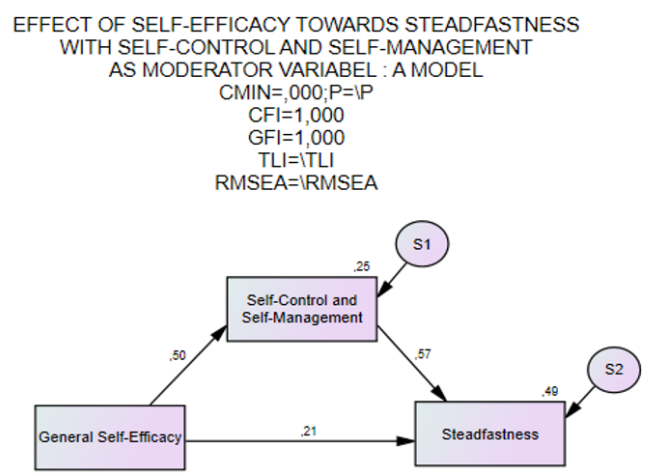

Fig. 1. Inter Variable Influence Model in Path Analysis.

Referring to Figure 1, according to the Goodness of Fit analysis, it can be seen that the two analyzes, namely Comparative Fit Index (CFI) and Goodness Fit Index (GFI) meet the criteria, which each shows 1,000 with a standard $>0.90$. Which means, although three other analyzes were not accepted, it can be concluded that the theoretical model is proven. Linkages between the three variables can be seen in Table 3 . 
Table 3. Inter-Variable Influence

\begin{tabular}{lccc}
\hline Variable & CR & P & $\beta$ \\
\hline SC and SM $\leftarrow$ SE & 10,120 & 0,001 & 0,503 \\
Steadfastness $\leftarrow$ SE & 4,437 & 0,001 & 0,210 \\
Steadfastness $\leftarrow$ SC and SM & 12,112 & 0,001 & 0,573 \\
\hline
\end{tabular}

In accordance with the standardized coefficients in Figure 1 and Table 3, it can be seen that there is an influence between self-control and self-management on steadfastness of 0.573 $(p<0.01)$ while the direct effect of steadfastness self-efficacy is $0.210(p<0.01)$. Which means, it can be said that selfcontrol and self-management play a greater role on steadfastness than self-efficacy.

If the influence between variables is viewed from its interaction, it can be seen in Table 4 . Based on the results of the analysis, it can be seen that self-efficacy has an effective contribution of $25.3 \%$ of self-control and self-management. While Table 5 shows the effective contribution between variables where the results show that self-efficacy has an effective contribution of $25.3 \%$ to self-control and self-management. While self-efficacy and selfcontrol and self-management contributed $49.3 \%$ to steadfastness.

Table 4. Inter-Variable Influence Viewed from the Interaction

\begin{tabular}{ccc}
\hline Variable & Direct Effect & Non-Direct Effect \\
\hline $\mathrm{SE} \rightarrow$ Steadfastness & 0,210 & 0,288 \\
\hline
\end{tabular}

Table 5. Effective Contribution Inter-Variables

\begin{tabular}{lcc}
\hline \multicolumn{1}{c}{ Variable } & $\beta$ & Effective Contribution \\
\hline SC and SM & 0,253 & $25,3 \%$ \\
Steadfastness & 0,493 & $49,3 \%$ \\
\hline
\end{tabular}

\section{Discussion}

This study aims to examine the theoretical model on four variables, namely self-efficacy, self-control, and self-management of steadfastness in memorizing the Koran on the Hafidz Koran in Indonesia. The theoretical model carried out in this study is selfefficacy influencing steadfastness with self-control and self-management as a moderator variable. Thus, the research hypothesis is "There is a direct effect between self-efficacy towards steadfastness and selfcontrol and self-management as a moderator variable".

Based on the results of data analysis, it is shown that self-control and self-management play a greater role on steadfastness than self-efficacy. This finding relates to the results of research which states that the ability of rehearsal or re-expressing is related to self-control [32] and the maturity of one's age [33]. In addition, in the previous study it was stated that persistence is positively and significantly related to self-control [34]. According to the study, someone who has stability in working on an activity, pursues a goal, and bears the difficulties of getting a better future actually has a higher level of selfcontrol. Therefore, the results of this study corroborates the previous studies. 
However, this finding was also inversely proportional to the results of research that showed that self-efficacy affected a person's persistence and persistence in doing assignments [35] In addition, Bandura [36] also stated that if a person has self-efficacy in pursuing his career then this can affect his learning in working to complete his work assignments, have goals to be achieved with his efforts and beliefs, and foster persistence in the face of difficult task.

Nevertheless, the results of the analysis showed that self-control and self-management were capable of being mediators between self-efficacy and steadfastness. Then it can be concluded that the indirect effect between self-efficacy and steadfastness with self-control and self-management as a moderator variable is more instrumental than the direct effect between self-efficacy and steadfastness. These results are in accordance with the results of previous studies stating that there is no correlation between selfefficacy and persistence in students undergoing the remediation process [37].

The findings mentioned above are supported by the existence of effective contributions between variables. Self-efficacy has an effective contribution of $25.3 \%$ towards self-control and self-management. While self-efficacy and self-control and selfmanagement contributed $49.3 \%$ to steadfastness. This finding is in line with the results of research that states that selfefficacy has a significant positive relationship with self-control [24], [39], [40]. Miswari also stated that in a learning process, the formation of self-management is an initial step in shaping self-efficacy [41]. It was also stated in the study that the existence of self-management in managing self-efficacy can be very supportive in achieving goals thus someone who is in the learning process can manage and organize themselves effectively and efficiently.

Based on the series of discussions above, it can be concluded that the hypothesis in this study is not proven. Which means, the contribution of selfefficacy to steadfastness is smaller than the contribution of self-control and self-management to steadfastness. The rejection of this hypothesis is inseparable from some of the limitations of this study. The first is related to the literature used. The researcher had limited access to literature, especially journals that discuss steadfastness. This is because theoretical studies and research results have not discussed much about this variable. Secondly, the researcher applied the trial concept used to adapt and make measuring instruments. In addition, the advantages of this study are that because the variables carried tend to be new in the realm of Islamic psychology, the results of this study are able to contribute to the realm of science. In addition, due to the large number of respondents, the results of this study can be generalized.

\section{Conclusions}

The results of model testing show that the indirect effect of self-efficacy on steadfastness with self-control and self-management as a moderator has a higher value than the direct influence between selfefficacy and steadfastness. Self-efficacy and selfcontrol and selfmanagement contribute a greater portion of steadfastness. Based on the results of the research that has been described, it can be concluded that the theoretical model of the effect of selfefficacy on steadfastness with self-control and selfmanagement as a moderator variable is proven empirically.

There are several limitations in this study, namely that there are not many previous studies related to steadfastness variable. In addition, related to the self-control measurement tool used, it is not clear which item that measures self-control and selfmanagement that both 
were combined in data retrieval by the researcher. Retrieval of data with Koranic memorizing respondents also still did not meet the ideal random sampling standard.

Therefore, the suggestion given to the next researchers is to pay more attention to the measuring instruments used in the research, understand the theoretical constructs about steadfastness, and pay attention to the sampling technique before at the stage of data collection.

\section{References}

[1] Safutra, I. Dari 240 juta warga Indonesia, hanya 30 ribu yang hafal Alquran. Diakses 2 Januari 2019, dari JawaPos (2017) https://www.jawapos.com/jpgtoday/26/01/2017/dari-240-juta-wargaindonesiahanya-30-ribu-yang-hafalalquran/\%3 famp.

[2] Umar. 2017. Implementasi pembelajaran tahfidz Al-Quran di SMP Luqman Al-Hakim. Jurnal Pendidikan Islam, 6 (1), 6-8. (2017)

[3] Nawabudin, A. Teknik menghafal Al-Qur'an, CV. Sinar Baru. Bandung. (1990)

[4] Nawaz, N., Jahangir, S. F. Effects of memorizing Quran by heart (hifz) on later academic achievement. Journal of Islamic Studies and Culture, 3 (1), 58-64. (2015)

[5] Tanjung, F., Lukmawati., Supriyanto, J. Al-qur'an itu menjaga diri: Peranan regulasi diri penghafal alqur'an. Jurnal Psikologi Islami, 3 (2), 94-105. (2017)

[6] Tasmara, T. Membudayakan etos kerja Islami, Gema Insani. Jakarta. (2002)

[7] Maimun, A., Agus, Z. F. Madrasah unggulan: lembaga pendidikan alternatif di era kompetitif, UIN Maliki Press. Malang. (2010)

[8] Seligman, M. E. P., Peterson, C. Character strengths and virtues: A handbook and classification, Oxford University Press, Inc. New York. (2004)

[9] Al-Qathany, S. M. Meniti jalan istiqomah, Pustaka Al Basyirah. Makassar. (2008)

[10] Mujib, A. Teori kepribadian perspektif psikologi Islam. Rajawali Press. Jakarta, edisi kedua. (2006)

[11] Nugraha, M. L. Pengaruh persistensi diri dan kebiasaan belajar terhadap kemampuan pemecahan masalah matematika di SMP Swasta Jakarta Timur. Research and Development Journal of Education, 2 (1), 12-14. (2015)

[12] Widiantoro., Purawigena, R. E., Gamayanti, W. Hubungan kontrol diri dengan kebahagiaan santri penghafal Alquran. Jurnal Psikologi Integratif, 5 (1), 11-13. (2017)

[13] Baumeister, R. F., Vohs, K. D., Tice, D. M. The strength model of self-control. Current Directions In Psychological Science, 16 (6), pp. 351-354. (2018)

[14] Mills, T. S., Rosiana, D. Hubungan antara self-control dan flow pada santri tahfidz Qur'an X Bandung. Prosiding, Psikologi Gelombang 2. (2014)

[15] Pujawati, Z. Hubungan kontrol diri dan dukungan orang tua dan perilaku disiplin pada santri di Pondok Pesantren Darussa'adah di Samarinda. Ejournal Psikologi, 4 (2), 227-236. (2016)

[16] Anggreini, R., Mariyanti, S. Hubungan antara kontrol diri dan perilaku konsumtif mahasiswi Universitas Esa Unggul. Jurnal Psikologi, 12 (1), pp. 35-36. (2014)

[17] Ardini, D. Hubungan manajemen diri dan orientasi masa depan dengan prokrastinasi akademik pada mahasiswa aktif kuliah dan organisasi. Vol. 5 (4), pp. 874-888. Studi pada anggota BEM KM Universitas Mulawarman Samarinda. Psikoborneo. (2017)

[18] Asim, T. M. Pengaruh bimbingan manajemen diri dalam meningkatkan kedisiplinan belajar siswa. Journal of EST, Vol. 2 (2), pp. 105-112. (2016)

[19] Mezo, P. G. The self-control and self-management scale (SCMS): Development of an adaptive selfregulatory coping skills instrument. Journal of Psychopathology Behavior Assess, 31, pp. 83-93. (2009)

[20] Bandura, A. Self-efficacy: The exercise of control, Freeman. New York. (1997) 
[21] Al-Baddareen, G., Ghaith, S., Akour, M. : Self-efficacy, achievement goals , and metacognition as predicators of academic motivation. Procedia - Social And Behavioral Sciences, 191, pp. 20682073. (2015)

[22] Kaiser, M. G. C. The influence of ethnic identity, gender, and trait anxiety on career decisionmaking self-efficacy for white and racial/ethnic minority students. Disertasi: Seton Hall University. USA. (2003)

[23] Mufidah, A. C. Hubungan antara dukungan sosial terhadap resiliensi pada mahasiswa bidikmisi dengan mediasi efikasi diri. Jurnal Sains Psikologi, 6 (2), 69-70. (2017)

[24] Bandura, A. Self-efficacy: Toward a unifying theory of behavioral change. Behavior \& Research Therapy, 1, pp. 139-161. (1997)

[25] Hurlock, E. B. Perkembangan anak, Penerbit Erlangga. Jakarta. (1978)

[26] Hess, T. M. Memory and aging in context. Psychological Bulletin, 131 (3), pp. 383-406. (2005)

[27] Sugiyono. Metode penelitian kuantitatif kualitatif dan kombinasi (mixed methods), Alfabeta. Bandung. (2016)

[28] Schwarzer, R. \& Jerusalem, M. Generalized selfefficacy scale. In Johnston, M., Weinman, J., Wright, S. C (Eds.), Measures in healh psychology: A user's portofolio (pp. 35-37), NFERNELSON. Windsor, UK. (1995)

[29] Bandura A. Social foundations of thought and action, Prentice Hall. Englewood Cliffs, NJ. (1986)

[30] Kanfer, F. H. Self-regulation: Research, issues, and speculations. In C. Neuringer., \& J. L. Michael (Eds.), Behavior modification in clinical psychology pp. 178-220, Appleton-CenturyCrofts. New York. (1970)

[31] Bandura, A. Social cognitive theory of selfregulation. Organizational Behavir and Human Decision Processes, 50, pp. 248-287. (1991)

[32] Gill, C. B., Klecan-Aker, J., Roberts, T., Fredenburg, K. A. Following direction: Rehearsal and visualization strategies for children with specific language impairment. Child Language Teaching and Therapy, pp. 85-103. (2003)

[33] Ormrod, J. E., Saklofske, D. H., Schwean, V. L., Harrison, G. L., Andrews, J. J. W. Principles of Educational Psychology, Person Education Canada Inc. Toronto, Ontario, Nanadian Edition. (2006)

[34] Galla, B. M., Duckworth, A. L. More than resisting temptation: Beneficial habits mediate the relationship between self-control and positive life outcomes. Vol. 109 (3), pp. 508-525. Journal of Personality and Social Psychology. (2015)

[35] Khormaei, F., Farmani, A., Yazdani, F. Predicting self-control on the basis of patience and its components among high school students. Research Papers, 5 (1), pp. 11-16. (2017)

[36] Mugiarso, H., Setyowan, N., Tedra, L. B. Selfefficacy dan persistensi mahasiswa ketika mengerjakan skripsi ditinjau dari kecemasan akademik. Teraputik Jurnal Bimbingan dan Konseling, 1 (3), 171-175. (2018)

[37] Valentino, R., Himam, F. Efikasi diri untuk meningkatkan optimisme terhadap pencapaian karir karyawan PKWT Perusahaan X. Jurnal Intervensi Psikologi, 6 (1), 53-54. (2014)

[38] Holmquist, C., Gable, R. K., Billups, F. D. The relationship between self-efficacy and persistence in adult remedial education. NERA Conference Proceedings, 17, pp. 1-28. (2013)

[39] Fang, X. P., Liu, J. P., Zheng, Z. G. The relationship among self-supporting personality, selfefficacy and self-control of undergraduates. Vol. 13, pp. 500-505. Studies of Psychology and Behavior (2015)

[40] Huang, W., Yang, Z. Goal orientation, self-efficacy, and self-control among 3-6 years old children. Pychological Development and Education, 31, pp. 547-554. (2015)

[41] Miswari. Mengelola self-efficacy, perasaan dan emosi dalam pembelajaran melalui manajemen diri. Cendekia, 15 (1), 67-82. (2017) 